\title{
Testing the Global Financial Transparency Regime
}

\author{
J.C. Sharman
}

\begin{abstract}
How can we tell whether rules that apply in theory actually do so in practice? Realists argue that the gap between what formal rules proscribe and their effectiveness may be particularly wide at the international level. Furthermore, dominant states may impose costly standards on others that they themselves choose not to implement. To test these propositions, the article assesses the effectiveness of international soft law standards prohibiting anonymous participation in the global financial system by seeking to break these standards. The findings indicate that the prohibition on anonymous corporations is relatively ineffective, and is flouted much more in G7 countries than tax havens. The article contributes to and extends the work of realist scholars in international political economy, both in its skepticism of formal rules, and focus on the effects of power. Evidence is drawn from the author's solicitations and purchases of anonymous shell companies from 45 corporate service providers in 22 countries.
\end{abstract}

\section{ACKNOWLEDGMENTS}

The author would like to thank Lee Morgenbesser, Jo-Anne Gilbert and Vanessa Newby for their research assistance, and acknowledge the financial support of Australian Research Council Discovery Grants DP0771521 and DP0986608. 
Rules are at the heart of the study of politics. But how can we tell whether the rules that apply in theory do so in practice? It is a commonplace that laws, regulations and policies can be a dead letter, completely ineffectual and irrelevant for actors’ behavior. Yet political scientists have rarely taken the most direct approach to testing the effectiveness of rules: attempting to break them, and seeing what happens. This paper practices just such a participant approach. It is based on seeking to violate recent global soft law standards prohibiting anonymous participation in the international financial system so as to assess the effectiveness of these standards. Such a test is especially apposite in looking at the effect of international rules, long argued by realists and others to be troubled by particular enforcement difficulties due to the lack of a world government.

The argument presented aims to build on the work of realist scholars in international political economy in two ways: first, by emphasizing a healthy suspicion of the practical effectiveness of international rules; and second by focusing on the power of dominant states to impose rules on others that they do not follow themselves. Relating to the first concern, the unusually direct approach to testing the impact of global rules helps to counter-act worrisome biases in much of the existing literature on global governance and international regimes, which tends to overstate the success of international rules. These biases have often meant that the study of global governance and international regimes has run counter to the general scientific presumption of favoring tough tests over easy ones (Popper 1968; King, Keohane and Verba 1994: 100). By providing a more direct and demanding test, a participation approach helps to rebalance empirical work in this area, as well as providing support for a realist scholars' skepticism 
about taking formal international agreements at face value. And whether as scholars or as citizens, when we ask “do the rules make a difference?” we are asking whether rules proscribing an activity (speeding, selling cocaine, torture, genocide, nuclear proliferation, polluting etc.) have made it significantly less likely that this activity will occur. In this context, an investigation premised on rule-testing by rule-breaking enjoys an advantage over less direct methods.

Turning to the second point, scholars working in the liberal tradition have focused on overcoming the obstacles to mutually advantageous co-operation in the production of international public or quasi-public goods. They have neglected the possibility that strong states might be able to hold others to international rules, while themselves opportunistically defecting and enjoying the benefits of free-riding. Realists have correctly argued that power plays a central and often under-rated role in setting international rules. They have usefully demonstrated that just because all states follow the same rules, this does not mean they benefit equally, or perhaps in some cases receive any benefit at all. But once again, they have generally overlooked the idea that dominant states may in practice be able to violate formal universal standards while forcing others to apply them. The existence of such a "do as I say, not as I do" logic of standard-setting has been obscured by the prevailing conceptual lens, but perhaps even more so by the lack of a direct method for testing who is actually enforcing formal rules, as opposed to just ritualistically endorsing them.

The standards in question arise from a recent international campaign to proof the international financial system against financial crime, especially money laundering, large-scale corruption and tax evasion. The proximate goal of this campaign is to ensure that the world's financial and banking systems are transparent: every actor and transaction within the system must 
be able to be traced to a discrete, identifiable individual. States and international organizations have diffused rules outlawing anonymous participation in global financial networks, a provision now legislated in over 180 countries (FATF 2007). Anonymity is forbidden precisely because it is so useful for those looking to perpetrate financial crimes.

This article tests the global transparency rules by seeking to break these same rules. The project is based on attempting to found anonymous companies which conceal the author's identity. Such a participant approach fills an important gap in our knowledge by providing direct, primary empirical evidence about the effectiveness of global governance in this realm. To the extent that the new emphasis on transparency renders these attempts difficult or impossible, this would comprise compelling testimony of the power to regulate the global financial system. But if breaking the rules by participating anonymously in the global financial system is easy, this provides a strong indication that, in this case, the rules reflect nothing more substantial than pious hopes.

The logic behind this research design is that a company is little more than an alternative legal identity. Because these legal persons can have their own bank accounts, to the extent the true owner of the company is hidden, all transactions processed through the corporate account become untraceable. Such a corporate veil is thus very useful for those looking to hide criminal profits, make or receive bribes, finance terrorists, or escape tax obligations. The research design involved electronically soliciting offers of anonymous companies from 45 different corporate service providers in 22 different countries, and collating the various responses. The next step was to purchase a sub-set of these companies to determine whether the prohibitions on anonymous corporate entities (and thus anonymous participation in the international banking system) that 
apply in theory actually obtain in practice. Beyond assessing the ease or difficulty of establishing anonymous bank accounts overall, this research design also tests relative effectiveness of rules in different types of countries. Specifically, it tests the claim that these global rules are much less effective in offshore financial centers than major OECD economies. Policy-makers in the major institutions of global economic governance have consistently acted on the basis that those small jurisdictions stigmatized as offshore centers or tax havens pose the greatest threat to the integrity of the financial system, and tend to facilitate the conduct of financial crime through providing strict financial secrecy (G20 2008, especially the sections on Promoting Integrity in Financial Markets; EU 2008; UN-World Bank 2007; FSF 2000, 2007; Senate 2008). Yet this presumption has remained largely untested.

To foreshadow the results, it is relatively easy to break the supposedly hard-and-fast rule prohibiting anonymous participation in the global financial system. Seventeen of the 45 attempts to solicit anonymous companies met with success. Of these, 13 of 17 approaches to service providers in OECD countries were successful, compared with only four of 28 in so-called tax havens. Establishing a corporate bank account while preserving this anonymity proved more difficult. Nevertheless, five of the solicitations were successful in obtaining offers for an anonymous company with an associated bank account without having to provide any certified identity documentation as to the true owner of the company and account. This success rate, indicating that the prohibition was effective almost ninety percent of the time, may seem like an endorsement of the existing rules; after all, no system is perfect. Furthermore, given the small sample size, a degree of modesty is in order. But the author's effort to procure anonymous corporate and banking services was a relatively amateurish, low-budget affair carried out in the 
absence of any formal legal training or advice, involving a budget of $\$ 10,000$. Even such a shoestring affair managed to break a central principle of global financial regulation relatively quickly, cheaply and without sanction (so far).

Furthermore, policy makers have constantly portrayed global standards as being "only as strong as their weakest link,” because of the ease of regulatory arbitrage. Thus US Treasury Secretary Larry Summers remarked in 2000: “As interdependence increases, each country is as vulnerable to financial crime as the weakest link in the chain.” (http://usinfo.org/wfarchive/2000/000203/epf405.htm). Gordon Brown similarly emphasized in 2006 that “[A]s terrorist finance operates on a global scale, we know that we are only as strong as our weakest links," before asserting that Britain and the US would lead the world to tougher financial standards (http://thesop.org/index.php?article=2773). Examples of such statements can be multiplied ad nauseam. Thus according to the logic of these senior British and American officials, even if only one or two countries are delinquent in enforcing global standards, they will crucially undermine the efforts of all the rest. The exceptions dominate the rule.

How does rule-effectiveness vary between the small states labeled as tax havens and OECD countries? Here the result is exactly the opposite of what most observers have maintained: with regards to financial transparency, small island offshore centers have standards that are much higher than major OECD economies like the United States and the United Kingdom. The centers with the highest standards are those like Bermuda, the British Virgin Islands, the Bahamas, the Cayman Islands and Panama which uniformly require extensive identity documentation before establishing a corporate entity, let alone a bank account. A second group of centers was less observant, allowing the establishment of anonymous shell companies, but generally requiring 
identification before opening a bank account. These included Belize, Hong Kong, Canada and Britain. The third group, represented by Somalia and, most surprisingly of all, the United States, are prepared to provide corporate bank accounts without proper identity documentation. Before 2008 in the United States and pre-2007 in the United Kingdom the situation was even worse, with providers offering companies with corporate accounts without the need for any documentation at all. This pattern of results completely contradicts the rather sanguine picture of rule-effectiveness painted by powerful G7 states and the international organizations they dominate, which are responsible for monitoring these standards. As is argued below, this provides a strong indication that powerful states are choosing to profit by not following the standards they have imposed on others. A stream of independent confirming evidence from various other sources tends to corroborate this impression.

In developing these points, the structure of the paper is as follows.

The first section reviews the literature on international rules to isolate problems of selection bias, endogeneity and formalism which in combination lead scholars to over-state the impact of international rules. While realists have correctly emphasized the importance of power in rulesetting, they have generally neglected the possibility that powerful states may induce others to follow rules the former are not themselves adhering to. Company ownership may seem like a minor legal quibble, but the next section shows how a succession of major policy reports have identified the prohibition of anonymous shell corporations as the lynchpin of efforts to combat financial crimes ranging from tax evasion, to money laundering, to corruption. The third section argues for the merits of direct participation and field experiment methods. Despite relative neglect, such approaches are suited not only for inspiring new hypotheses, but also in testing 
hypotheses, even at the level of global governance. The article then describes the procedure for gathering evidence (soliciting and buying anonymous financial arrangements), and presents the findings. Chief amongst these are that international rules proscribing anonymous corporate entities are largely ineffective, though accessing anonymous banking is much harder. Prevailing double-standards, imposed and maintained by power, mean that the failure to apply international standards is more pervasive in G7 centers, especially the United States, than in small island countries. The conclusions of the direct test are buttressed by evidence from a variety of other sources, while a brief account of the Bahamian experience with international corporate transparency rules illustrates the coercive "do as I say, not as I do” logic at work.

\section{A Realist Perspective on International Rules}

Realists have strongly argued that international covenants and rules are often empty formalities with no independent effect on actors' behavior. Yet substantiating this judgement generally requires some way of assessing whether the international rules that should apply in

theory do so in practice. In general, Simmons notes that "In the face of daunting conceptual and methodological issues, very little evidence has been accumulated to assess basic propositions about why governments commit to and comply with international legal obligations, and whether this makes any difference to outcomes in which we are interested" (Simmons 2000: 832). But the evidence that has been collected often presents an artificially positive picture of the impact of international rules. Reviews of the compliance literature (Simmons 1998; Raustiala and Slaughter 2002) note that many studies of compliance tend to overstate success (see also Haas et 
al. 1993: 17-18). First there is a bias because of selection effects: only 'easy' issues tend come up for international negotiation in the first place. The second bias is endogeneity: governments may only sign up to commitments that they think it will be in their interest to keep (as demonstrated below, the global financial transparency regime is an exception). When behavior is compliant with the rules it is very difficult to show that compliance is occurring because of those rules, as opposed to merely reflecting what the actor would have done anyway.

In the current study, what is it exactly that is being tested? To answer this question it is important to have a clear understanding of the related yet distinct concepts of compliance and effectiveness. The most common definition of compliance in International Relations is that of Oran Young: "Compliance can be said to occur when the actual behavior of a given subject conforms to prescribed behavior, and non-compliance or violation when actual observed behavior departs significantly from prescribed behavior" (1979: 3). On this view, compliance is different from effectiveness (the effect on the underlying policy problem, for example torture, polluting or money laundering). Compliance, whether states' behavior corresponds with rules, may be necessary for effectiveness, but it is definitely not sufficient (Simmons 1998: 78). However things do not stay this clear for long. Raustiala and Slaughter observe that because compliance is above all concerned with how legal rules affect actual behavior, notions of compliance and effectiveness tend to blur. The level of compliance may in fact say nothing about the impact of rules on behavior (2002: 539), i.e. the outcome that is of most interest to scholars, policy-makers and citizens alike (Nye 1993: ix). Studying compliance in isolation thus poses a danger of formalism, falsely depicting a rule-governed world. Drezner agrees that "governments often make pledges to co-ordinate without actually doing so" (2007: 12). Indeed, this basic 
objection centering on the ineffectiveness of international rules is central to realist work (Carr 1939; Mearsheimer 1994/95). Such biases mean that empirical tests of global rules often provide only relatively easy, and thus less valuable, tests that tend to confirm the hypothesis that international rules do make a difference.

The test performed in this article relates to perhaps the single most constant preoccupation of those working in International Relations since the 1980s: explaining whether, when and why states adhere to common rules for mutual benefit (Keohane 1984; Baldwin 1993; for the most recent 'contractualist' take, see Lake 2007). Realists have made important contributions in foregrounding the exercise of power with reference to international standards, but have also tended to overlook an aspect of the problem at the heart of this article. Specifically, the oversight is the ability of dominant countries to establish 'hypocrite standards': costly common rules imposed on lesser states but not implemented by the dominant states themselves. Here it is important to situate the contribution of this article within broader realist literature. Leading realist commentators on political economy questions like Krasner, Gruber and Drezner all premise their work on what they see as the insufficient attention devoted to power in explaining international rules (e.g., Krasner 1977: 670; Krasner 1991: 342; Gruber 2000: 10; Drezner 2007: xiii). The main issue for each is how powerful states can induce others to comply with the rules that disproportionately advantage the strong. Thus in writing on global communication standards, Krasner (1991) persuasively argues that the presence, absence and nature of regimes is determined by states' relative power. Dominant states are able to impose their preferred standard and pick their favored point on the Pareto frontier, claiming for themselves a larger share of the benefits that eventuate, though no party is worse off from co- 
ordinating standards. The rules in question are biased toward the strong, but they are followed by strong and weak alike.

Lloyd Gruber (2000) takes this realist logic a step further. His innovation is that states may accede to international standards even when these standards leave them worse off than the status quo. Powerful states may exercise 'go-it-alone’ power by clubbing together and establishing institutions or rules that act to remove the status quo as an option for outsiders. Under the changed circumstances states outside the club are presented with a bad option or a worse one: the first is to join up even though this will leave them worse off, the second is to pay an even heavier penalty for remaining isolated. All relevant states thus adhere to the new rule, either because they are genuinely better off, or because it is the least-bad alternative open to them. Again, all follow the same rules. Drezner (2007) holds that regulatory regimes are a product of the level of agreement within and between great power and lesser state groupings, creating a four-part typology. Where all are in agreement, there are harmonized standards. Where none is in agreement, there will either be no regime, or notional 'sham standards,' rules which remain only on paper. Where the great powers are split but each can secure allies among other lesser states, competing 'rival standards' will result. Finally, where the great powers are in accord on their preferred rules, but those on the periphery are opposed, these 'club standards' will be coercively imposed as far as possible. But like Krasner and Gruber, Drezner does not consider another vital prerogative of power: the ability of the strong to impose rules on others that they have no intention of following themselves. Perhaps a fifth type to Drezner's classification might be 'hypocrite standards': ostensibly universal standards that the great powers impose on others, 
but in practice do not observe themselves. By this means great powers can shift the expense of adjustment elsewhere, while opportunistically exploiting widespread rule-observance by others.

Rather than this point being only of interest to realists, it goes to the heart of other work on co-operation also. In the Prisoner's Dilemma rendering, neo-liberal work has fixated on gaining the benefits of co-operation while avoiding sucker’s pay-off. But of course for any individual player, the most preferred outcome is not co-operation, it is unilateral defection when all other players are co-operating. Under the highly-stylized parameters of the game, where coercion is forbidden, this is generally impossible (or at least not an equilibrium outcome). In the real world, however, and particularly in the context of the global financial transparency regime, this is not the case. For example, from the point of view of the United States, the ideal world is not one where there are no havens for foreigners to hide money away from tax collectors; the ideal world is where the United States is the only such haven. Every other country bears the costs of being financially transparent so as to assist the United States collect its taxes, while the United States is opaque, benefiting from the illicit capital invested in its economy. Lest this example seem too farfetched, it is worth considering the verdict of one of the most authoritative commentators on international tax issues over the last 50 years:

It does not surprise anyone when I tell them that the most important tax haven in the world is an island. They are surprised, however, when I tell them the name of the island is Manhattan. Moreover, the second most important tax haven in the world is located on an island. It is a city called London in the UK (Langer 2008: 9). 
Although the detailed empirical material is left until the following sections, it is worth noting that the US levies no taxes on the dividends, interest or capital gains on foreigners investors, and has studiously ignored requests to exchange such financial information with the Mexican and other governments whose citizens use the US to hide illicit wealth (see Goulder 2009). Among others, the American Bankers’ Association has consistently and successfully argued that if such information were provided to foreign governments, the United States would suffer a massive loss of much-needed foreign deposits, valued at \$2.6 trillion in 2007 (www.aba.com/NR/rdonlyres/AF4BE30B-E70C.../HWaLetter0227095.doc).

In the instance of financial transparency, and perhaps more broadly, the existence of this “do as I say, not as I do” logic of international regulation has been obscured by an excessive preoccupation with universal formal rules, rather than the actual pattern of effectiveness. Publicly proclaiming such hypocritical double-standards runs against prevailing standards of legitimacy. As long as the field has lacked a direct means of testing effectiveness, the possibility that strong states can in practice flout the same rules they publicly support and impose on others has been overlooked. And of course because the organizations that monitor compliance with these international standards are disproportionately funded and influenced by powerful states, they have a strong incentive not to blow the whistle. The Nuclear Non-Proliferation Treaty might be another (unusually obvious) example. In principle Article VI states: "Each of the Parties to the Treaty undertakes to pursue negotiations in good faith on effective measures relating to cessation of the nuclear arms race at an early date and to nuclear disarmament, and on a treaty on general and complete disarmament.” But in practice it allows nuclear weapons for the powerful few while barring them to the rest. 
More broadly, in looking to advance such a realist argument the article seeks to help remedy the situation whereby realism has become, as one sympathetic observer noted, a “diminished voice” in International Political Economy scholarship (Kirshner 2009: 46). It could be objected that partisans of a particular orientation love to portray themselves as an embattled and under-appreciated minority (Mearsheimer 2001: 22-25). But in their detailed and systematic review of International Political Economy articles in 12 leading journals 1980-2006, Maliniak and Tierney note that realist contributions usually comprise less than five percent of the published output in these venues. Realist contributions are disproportionately used as "counterarguments, framing devices and straw-men” (2009: 16). The purpose of reintroducing a realist perspective is not diversity for its own sake, nor the protection of some intellectual endangered species, but better explanations. No lesser figure than Robert Keohane has recently noted his “gnawing dissatisfaction” with reigning liberal IPE perspective of free agents consensually contracting for mutual advantage (Keohane 2009: 37), in part because of the blind spot regarding the role of power. Keohane notes how IPE overall has suffered from a dearth of realists pushing others to be cognizant of coercion and domination (2009: 39). The results below seeks to show how marrying a realist outlook with an unconventional method can produce valuable new insights.

\section{The Significance of Anonymous Shell Companies}

Discovering who is really behind corporate vehicles and their bank accounts may sound like a trivial, esoteric accounting matter. In fact, it is the linchpin of some of the most important 
global governance initiatives (see G20 2009). These include the fight against tax evasion, efforts to stem corruption and corporate malfeasance, and the campaign to counter money laundering and the financing of terrorism. This section establishes that individual countries and international organizations have recognized the matter of anonymous corporate vehicles as a significant policy issue. One of the first reports to put the issue of anonymous corporations at center stage was commissioned by the United Nations in 1998. Financial Havens, Banking Secrecy and Money Laundering explains that "Despite a myriad of complications, there is a simple structure that underlies almost all international money-laundering activities... The launderer often calls on one of the many jurisdictions that offer an instant corporation manufacturing business.... Once the corporation is set up in the offshore jurisdiction, a bank deposit is made in the haven country in the name of that offshore company” (1998: 2). The authors emphasize that secrecy regarding the ownership of a corporation is a much more serious obstacle to countering money laundering than banking secrecy as such (1998: 31). Subsequent analysis by the Financial Action Task Force on money laundering (FATF) has reiterated this conclusion that shell companies and other vehicles, set up by Corporate Service Providers like those contacted in this study, are fundamental to financial crimes (FATF 2006). Thus in December 2009 a report dedicated to this issue stated:

The FATF has for many years noted the importance of corporate vehicles as one of the key mechanisms used in money laundering schemes... Indeed the beneficial ownership of legal persons is important not only for anti-money laundering purposes, but is also fundamental for other important areas such as anticorruption, corporate governance and work to combat tax evasion, to name a few (FATF 2009: 2). 
In 2001 the OECD released the report Behind the Corporate Veil: Using Corporate Entities for Illicit Purposes, responding to a request from the Financial Stability Forum to investigate the problem of anonymous corporations. The report was subsequently endorsed by the G7 finance ministers (2001: 3). Corporate entities where the beneficial ownership is obscured are said to be central to all economic crimes: tax evasion, money laundering, fraud, corruption, insider trading and others. It is said that they may in the aggregate even imperil the stability of the global financial system (2001: 7; see also G20 2008). Offshore centers are said to be particularly at fault through their provision of shell corporations (2001: 24). More recently, a 2009 World Bank study authored by Richard Gordon sought to discover how corrupt heads of state and other senior politicians launder the bribes they receive. The key features identified in the report are anonymous shell companies and accounts linked with such entities (2009: 15 and 22), confirming the empirical focus of the participation exercise at the heart of this paper. Echoing others, Gordon notes that the most common alibi for these funds is “consultancy fees” (2009: 18). (Gordon also notes that it is just as likely for onshore vehicles and banks to facilitate the laundering of the proceeds of grand corruption as those in small island offshore centers (2009: 16).) In resolving this problem, however, it is not so much a case of introducing new international principles and standards as making those already on the books effective. A slew of global standards mandate the imperative for financial institutions to "Know Your Customer,” meaning that beneficial ownership of corporate vehicles must be established (see Table 1 for a sample). FATF Recommendation 33 clearly states: “Countries should ensure that there is adequate, accurate and timely information on the beneficial ownership and control of legal persons that can be obtained 
or accessed in a timely fashion by competent authorities.” There is no question that the formal rules are in place; the great unknown is their effectiveness.

***TABLE 1: PROHIBITIONS ON ANONYMOUS COMPANIES \& ACCOUNTS***

\section{Why a Participant Approach?}

There are international laws and conventions against torture, corruption, gender and racial discrimination and drugs, yet the existence of these instruments tells us nothing about their practical effectiveness. Common sense suggests that the gap between laws and standards may be very wide. A participation approach, in this case assessing the effectiveness of a rule by trying to break it, gives a particularly acute sense of the magnitude and incidence of this gap. This kind of approach is rare in political science, but is closely related to field experiments (though importantly without randomization, due to the lack of a treatment). A common objection to field experiments has been that individual scholars can only test small questions, as opposed to the overarching issues of most interest to the field, especially issues in International Relations (Green and Gerber 2002). A first reply would be that even localized, direct interventions or participation can provide inspiration and insight on very important macro matters, up to and including global governance. Even on an informal basis, participant-observation has provided the stimulus for some of the most influential recent work on international organizations and global governance. Barnett and Finnemore trace their dissatisfaction with conventional wisdom on international organizations to their time working with the United Nations and the World Bank, respectively 
(2004: vii). From a very different theoretical orientation, Daniel Drezner relates that the formative incident for his realist account of global regulatory regimes took place during a year spent with the US Treasury (significantly, this incident concerned standards prohibiting of corporate and banking anonymity, 2007: xii).

But if the uses of participant-observation and field experiments have been underappreciated in generating propositions about international organizations and global governance, the same goes doubly for testing such propositions (Green and Gerber 2002: 808). An example from economics of the utility of a direct approach in testing propositions is represented by "Are Emily and Greg more Employable than Lakisha and Jamal? A Field Experiment in Labor Market Discrimination.” Here the authors sent fictitious resumes in response to job advertisements in Chicago and Boston, randomly assigning black- and white-sounding names to measure the effect of perceived race on employability. Even allowing for perceived class differences, the authors found that perceived race did make a pronounced difference. With identical resumes, white names received 50 percent more requests for interviews (Betrand and Mullainathan 2004). The conclusion drawn was that racial discrimination is still a major factor in the US job market, with crucial implications for the life-chances of black Americans.

An even more closely analogous method to that employed in this article is that used by Hernando de Soto and his team of researchers looking at the causes of worldwide development failures $(1989,2000)$. De Soto makes the obvious and yet under-appreciated point central this article that "Reading the laws as they are written gives no clue to how they will work in practice" (2002 [1989] xxii). In seeking to test their notions about the difficulty of entering the formal economy in the Third World, his team performs a number of what are referred to as 
'experiments' or 'simulations.' The team applies for a sole trader license to produce textiles in Lima, Peru following all the requirements of the law and bureaucratic procedure. The researchers carefully recorded all the time spent filling out forms, waiting for official permission and dealing with bribe requests, mimicking as closely as possible the approach of a genuine applicant (2002 [1989] 133-34). They found that even this seemingly simple task required 11 separate procedures, taking 289 work days and cost the equivalent of 32 times the minimum monthly wage in lost profits, not counting the bribes that had to be paid. De Soto's team later repeated equivalent experiments in Egypt, Haiti and the Philippines, with similar results (2000: 20-21). The findings give significant support to the proposition that it is extremely hard for those stuck in the underground economy in developing counties to enjoy formal property and other legal rights, which in turn greatly raises the barriers to overall national economic development.

The scale, ambition and significance of these studies disproves the notion that participatory and field experiment designs must be limited to small questions and minor concerns. Neither do the geographical restrictions that characterized pioneering work in this vein in political science still obtain (Gosnell 1927). Of course these can be surmounted in a largebudget exercise involving a team of international researchers, as per de Soto (2000). But even when such means are lacking, modern communications can provide an answer. Working alone, the author tested the regulatory regimes of over 20 different countries without the necessity of international travel. The solicitation stage of the exercise required no funds, while the budget for purchasing shell companies and associated bank accounts was relatively modest (c. \$10,000).

\section{Soliciting and Purchasing Anonymous Shell Companies}


The first step in the participation exercise was to compose a short approach email to corporate service providers. This was designed to mimic the profile of a representative would-be miscreant, based on recurring elements identified in the reports of the international organizations referred to above. The first is the anonymous company itself. The approach letter asked for the provision of such a company, and emphasized the need for confidentiality and tax minimization. The second is the nature of the business activity: international consultancy. Consulting fees are often a useful cover story for illicit cross-border flows (World Bank 2009: 18). Because there is a very large volume of legitimate money being moved around for this purpose, such transactions do not stand out as being unusual. Consulting fees may be very large, providing an alibi for large sums of criminal proceeds. Because consultancy does not involve the exchange of physical goods, and unlike many other services does not require buyer and seller to be in the same location, it is very hard to prove that a consultancy arrangement was not in place. The letter involved a permutation of the author's real name. This was done so as to avoid the legal consequences of signing financial documents in a fake name, but also to complicate the efforts of corporate service providers to link the person in the approach letter to the author's related publications.

After designing the approach letter, the next step was to identify relevant corporate service providers, those firms whose business it is to establish and provide basic administration for shell companies, trusts, foundations and so on. The aim here was to include service providers from a range of G7 countries that are portrayed (or at least portray themselves) as leaders in Know Your Customer standards like the United States and Britain, as well as jurisdictions that 
have commonly been stigmatized as tax havens. Specific providers were identified through advertisements in the Economist and in offshore finance magazines like Offshore Investment. The sample included a range of both on- and offshore centers in terms of the location of the service providers, and the specific corporate entities they offered (there is no necessary reason for providers to offer companies only from their home jurisdiction). This sample was achieved by targeted web searches for service providers and entities in rough proportion to their national share of the total market. Also taken into consideration was the range of perceived stringency and laxity of regulatory standards according to international assessments from bodies like the OECD and FATF. Such sampling allows for testing the proposition that powerful states will choose to enforce financial transparency standards less stringently than small states. The selection process was necessarily somewhat ad hoc, as with conflicting or non-existent national definitions of corporate service providers, there is very limited knowledge of the total population or distribution of such agents (FATF 2006). The selection process for service providers was deliberately not just an effort to comb the murkiest recesses of international finance to find the most secretive or scoff-law providers.

This test was premised on an a fortiori logic: if even a relatively limited search turned up anonymous products, then how much easier would it be for the criminals that the global transparency regime is designed to stop? Similarly, choosing easy-to-find providers with a relatively high profile also acts as a tough test of the argument concerning the ineffectiveness of the rules. These kind of providers should be most visible to those responsible for enforcing the regulations, and thus most likely to be applying the rules. Fifty-four service providers were contacted, of which 45 returned valid replies. In the valid replies, service providers recommended 
one or more corporate structures that could achieve the goals set out in the approach letter, together with a pricing schedule. These replies were tabulated in terms of whether the service provider would supply anonymous vehicles, and then whether this anonymity could be maintained in establishing an associated bank account (see Table 2 at the end of the paper).

Where the response made provision of the company and/or bank account conditional on notarized copies of a passport together with birth certificate, utility bills and the like to establish identity and residence, this was coded as not anonymous. It would have been impossible to shield true identity short of falsifying these documents (i.e. committing fraud). Where the corporate service provider required only name, address, credit card details, etc. to be entered into an online form without any supporting documentation, this was coded as anonymous (remembering that credit cards can be issued for corporate vehicles or supplied by a third party). By definition where the third party has no information as to the real owner, they cannot hand over any information to investigating authorities, representing a guarantee of anonymity. In relation to five bank accounts, providers asked only for an electronic scan of an identity document like a driver's licence, but there was no requirement to have it notarized or certified as a true copy. These are individually noted in Table 2 . While indicating some concern with establishing beneficial ownership, this does not meet the international standards in Table 1. Rather than stopping with offers of anonymous entities and bank accounts, it was necessary to go through and make the purchase from a sample of the service providers.

\section{Findings}


Table 2 presents the aggregate results of approaches to different service providers. Of the 54 Corporate Service Providers approached, 45 indicated a willingness to provide a shell corporation, the first step. Of these, 28 required identification before establishing companies (a notarized copy of a passport, usually complemented by utility bills as proof of residential address, as well as sometimes bank or professional references), while 17 were content to form the company without any independent confirmation of identity, requiring only a credit card and a shipping address for documents. Although the cost varied, in all cases establishing an anonymous shell corporation is a cheap proposition, ranging from $\$ 800$ to $\$ 3000$ as an up-front cost followed by a slightly smaller amount on an annual basis. The cost variation is generally explained by the optional extras, in particular the extra layers of secrecy, but also various corporate accessories and accoutrements (mail- and phone-forwarding, brass plate, rubber stamp, letter head, embossed seal, etc.). Relative to the corporations requiring identification checks, the anonymous vehicles were slightly cheaper, depending on the accessories purchased.

Where the service provider has proof of the individual's identity, the veil of secrecy is vulnerable to being pierced. Particularly in countries with strong domestic investigative powers, local law enforcement may seize beneficial ownership documentation if such material is held by the corporate service provider within their jurisdiction. The United States has premised its strategy for controlling the existence and proliferation of anonymous shell companies on such strong investigative powers. The fatal flaw in this plan, as the OECD points out, is that it depends on local service providers having collected the ownership information in the first place (OECD 2001: 10; see also FATF 2009: 6), which is precisely the problem in the United States. 
Even leaving aside cases where the service provider is in the same jurisdiction as the investigative authority, however, the range of risks spreads much further. First because the hosting jurisdictions are vulnerable to pressure from foreign governments to hand over client identity documentation. For example, after repeated public assurances that the Cayman Islands would not join the EU's tax information exchange program, Britain successfully obtained a reversal by threatening to suspend the Caymans’ self-government (Sharman 2008). Second, service providers themselves are vulnerable to the same sort of outside pressure. A case in point is the Swiss bank UBS, which only a few years after sending its US clients a soothing email guaranteeing them that it would never pass their details to the IRS, passed over the details of clients to the IRS (Sheppard 2009). Finally, rogue employees of the service provider like Heinrich Kieber of Liechtenstein’s LGT bank may leak sensitive material (in Kieber’s case relating to 4,500 accounts in return for $€ 4.2$ million from the German intelligence service, see Fisher 2008). Clearly, however, if the service provider has no information to disclose, these threats to the integrity of the corporate veil are all obviated.

The results in Table 2 show that forming an anonymous shell company is a cheap and easy proposition. Following from this, the rules directly prohibiting such arrangements (see Table 1) are ineffective. An analysis that assumed that the mere presence of formal international rules prohibiting anonymous shell vehicles indicated that such vehicles were impossible, or even difficult, to obtain, would be wrong. Despite the near-universal coverage in terms of the countries that have committed to these rules, a significant number have merely adopted sham standards. Perhaps even more striking than the ease with which this rule can be violated, is the pattern of jurisdictions that routinely violate this rule. Here the results are closely in line with the 
proposition of 'hypocrite standards': service providers in powerful OECD states are much more likely to offer anonymous shell companies (i.e., are much less likely to enforce international rules) than those in small islands. Thus attempts to incorporate anonymously with providers in the Bahamas, Bermuda, the British Virgin Islands, the Cayman Islands, Dominica, Nauru, Panama and the Seychelles all met with failure, in that these agents refused to proceed without proof of identity. In nearly all cases these agents explicitly noted that anti-money laundering regulations necessitated their keeping this information on file. Even the Liechtenstein-based agent of the Somali International Financial Center required notarized passport copies (though they were much less stringent about bank accounts, see below). One provider in Belize offered to incorporate a Belize shell company without identity documents, as did another in Uruguay for Seychelles companies, and one each from Hong Kong and Singapore regarding Delaware and other offshore companies.

Yet of the 17 providers in OECD countries approached, no less than 13 agreed to form shell companies without requiring identification documents. These comprised seven in the UK, four in the United States, one in Spain, and one in Canada (the sole Swiss and Czech providers responding were more scrupulous). Of these 13 providers, only one limited its stock to offshore shell companies (from Belize), three of the US providers offered only American companies, while the remaining US, the Canadian and all the British providers sold a mix of onshore and offshore vehicles, in some cases from more than 30 jurisdictions. In every case, whether or not identity documentation was required was a function of the location of the provider, not the domicile of the legal entity created (i.e. a British Virgin Islands company created from Britain would be anonymous, whereas one established from the Bahamas would not be). Although the 
sample size is small, these findings suggest that the problem of financial opacity is one for which the G7 countries, particularly the United States and Britain, are responsible, not palm-fringed tropical islands. While not an unprecedented finding, this does diametrically contradict the initial premises of important global regulatory campaigns. Although nearly all offshore centers regulate corporate service providers, Britain and the United States have chosen to leave them unregulated. The consequences are clear.

An example of one shell company set up for this paper, André Pascal Enterprises, may prove illustrative. The company is an England and Wales Private Company Limited by Shares (with bearer shares) set up by a UK provider. Upon payment and submission of the order, the provider electronically lodged the application with UK Companies House. The provider became the initial shareholder of the company and subscriber to the Memorandum and Articles of Association for the purposes of the government records. Upon receipt of signed documents (once again, without the need supporting identification), the provider issued bearer share warrants, erasing the provider’s name from the share registry without substituting any other. André Pascal Enterprises had a nominee director and nominee secretary (once more courtesy of the provider), again providing separation from the beneficial owner (the author). The incorporation process took less than a day, filling out the on-line forms took 45 minutes and the total cost was GBP 515.95. The new legal person is the kind of classic anonymous shell corporation so important for perpetrating a wide range of financial crimes, and which is almost impossible to obtain from offshore providers. The bonus is that as a corporate citizen of the UK, André Pascal avoids the taint associated with offshore companies while securing much tighter secrecy, an advantageous combination remarked upon by a number of other providers (see also BCP Consolidated 
Enterprises (Nevada), below). Significantly, until 2006 the same UK provider offered corporate accounts at a Latvian bank without the need for any supporting identity documentation.

Given that an anonymous shell corporation is generally a prerequisite for entering the international banking system while keeping one’s identity secret, the 17 providers offering anonymous corporations became the target sub-set. In seeking to purchase a bank account associated with an anonymous company the author soon ran into requirements for notarized identity documentation from all but five providers. Thus the general effectiveness of the prohibition on anonymous accounts is substantially higher relative to that regarding anonymous shell companies. But the pattern of ineffective rules for providers in G7 states compared with those in so-called tax havens largely remains. At first glance this high level of overall effectiveness (40 from 45) may seem to rehabilitate global standards on financial transparency; if a shell company is redundant without access to a banking system, and if anonymous companies are barred from the banking system, then the failure to prohibit corporate secrecy is much less serious, particularly for delinquent countries like the US and UK. The difficulty of obtaining anonymous corporate accounts does mark an important change from the situation a decade ago (UN 1998). But even without direct access to the banking system, anonymous vehicles can be useful in financial crime. One of the most common forms of international tax evasion is holding share portfolios in the name of a foreign shell company so as to avoid capital gains tax that would be due at home. More importantly, in a chain of corporate entities even one anonymous vehicle (e.g., a company acting as a director of another company or as a trustee) can disrupt the effort to establish the true owner at the end of the chain, rendering the whole structure opaque. Companies can be re-domiciled or transferred to re-establish anonymity broken in the process of 
setting up an account. Finally, however, the fact that it is difficult to retain corporate anonymity while opening a bank account is not to say it is impossible.

Only a small number of providers that responded to author were deficient in requesting proper identification documentation. The first, and most flagrantly in breach of international standards was a US provider offering a Wyoming Limited Liability Corporation with a US bank account. The provider offered to use their employees' own Social Security Numbers in applying for an Employer Identification Number (EIN), the tax identification number for the corporate vehicle. As the provider breezily informed the author in an email: "You can open a bank account in any state in the nation. It does not have to be in Wyoming. You will need an EIN number for the LLC, which we may be able to get for you, if you elect the nominee tax ID service. There are no supporting documents required at this time, outside of your contact information.”

Disappointingly for would-be criminals, in the months between this receiving this email and going ahead with an attempt to buy this structure, the laws in Wyoming changed to prevent this particular service being offered. Yet of all the countries appearing in Table 2 the United States remains in dead last place in terms of corporate and banking due diligence, behind even Somalia. A revealing comparison chart from a service provider specifies the documentation necessary to open a bank account in various countries, along with an overall difficulty rating (http://www.offshoreinc.net/new_bankcomparison.shtml). This ranges from 'very high' (Seychelles, Jersey), to ‘high’ (Hong Kong, Singapore), to ‘medium’ (Cyprus, Dominica); the United States is the only country ranked as 'low,' allowing accounts to be opened with an unnotarized copy of a driver’s license. 
To test this ranking directly, the author established two companies with accounts in 2009, a classic offshore structure and an onshore equivalent. The first example involved approaching a large service provider in Singapore and buying the most secret vehicle and bank account available. This was a Seychelles company (Gruppo 20 Enterprises) formed with a nominee director and bearer shares, the latter meaning that whoever holds the physical share certificate owns the company. The accompanying bank account was in Cyprus, picked on the advice of the service provider because of this bank’s unfastidious willingness to accept bearer share companies. Despite being the most laissez faire offshore bank available, the Cypriot bank still required a notarized physical passport copy, original bank reference, and original utility bill before opening the corporate account. These are also required for any person subsequently given signatory power over the account. Establishing the company and opening the account cost $€ 1754$. The second, onshore vehicle, BCP Consolidated Enterprises, is a Nevada corporation set up by a Nevada service provider with a nominee director and nominee shareholders. As such, the author's name appears nowhere on the incorporation documents, but in any case Nevada refuses to share tax information with foreign authorities. BCP Consolidated then opened an online bank account with one of the top five US banks. The cost of establishing the company and the bank account was \$3695. Neither the original service provider nor the bank required more than an unnotarized scan of the author's drivers license (showing a outdated address). Thus even the laxest offshore bank has due diligence standards far higher than those applied by major US institutions.

The final case, the Liechtenstein-Somali joint venture, is unusual in having stricter requirements for establishing a company compared with opening an account. While setting up a 
Somali shell company explicitly requires a notarized passport copy, both the provider's website and email communications repeatedly note that, although they require a scanned copy of some piece of photo identification, there is definitely no need to get this notarized or certified as a true copy in opening a bank corporate account. The repeated emphasis on this last point suggests that the providers are broadly hinting at the possibility of a de facto anonymous account. The author tested this by successfully establishing first a personal account (€300), and then a second USdollar corporate account for BCP Consolidated Enterprises (Nevada) in Somalia via a major Italian bank, for another €300. This required only a scan of the author’s unnotarized driver’s license (again, showing an old address), and the company's Articles of Association (which, to repeat, includes only the nominees' names rather than author's). Thus rather than one of the 'usual suspect' island tax havens, only a failed African state provided corporate banking facilities with as little due diligence as the United States.

\section{Independent Confirming Evidence}

The goal of this penultimate section is two-fold: first to provide independent confirming evidence of the results of the direct test above, and second to illustrate the pressures that explain why small states have been so diligent in applying the standards flouted by the United States and others. Regarding the first point, as discussed earlier, powerful states are unlikely to stir up needless controversy by admitting their lax enforcement of the rules they impose on others. The international clubs they fund and dominate have a strong incentive to overlook their patrons' failings (e.g. the G20, the OECD and the FATF). This problem notwithstanding, however, there 
is good evidence from a variety of sources to support the conclusion that the United States in particular, but also other OECD countries, are less stringent in applying the rules on corporate transparency than offshore centers. Evidence is taken from six independent sources: the NGO Tax Justice Network, the World Bank, the United States Senate, a study for the European Commission, the world's major Anti-Money Laundering software firm, and a more restricted direct test like that performed above.

In November 2009 the NGO Tax Justice Network released a Financial Secrecy Index, “a ranking which identifies the jurisdictions that are most aggressive in providing secrecy in international finance, and which most actively shun co-operation with other jurisdictions” (http://www.financialsecrecyindex.com/). Sixty jurisdictions were each assessed against 200 variables. The index aims to measure a broader range of factors than just the transparency of shell companies, but the results are broadly in agreement with those presented in the previous section. Thus the worst offender by a large margin is Delaware (the only US state assessed), followed by Luxembourg, Switzerland, the Cayman Islands and the United Kingdom. The Tax Justice Network concludes:

The major global players in the supply of financial secrecy are mostly not tiny, isolated islands, but rich nations operating their own specialized jurisdictions of secrecy, often with links to smaller 'satellite' jurisdictions which act as conduits for illicit financial flows into the mainstream capital markets.

Commenting on this unflattering conclusion, one local pointed out "Delaware is no more secret than any other U.S. state,” given that the others also fail to collect beneficial ownership information (http://www.reuters.com/article/domesticNews/idUSTRE59U1VB20091101). 
In the same week Senator Carl Levin issued a damning statement regarding American delinquence in meeting international standards:

Our 50 states are forming nearly 2 million companies each year and, in virtually all cases, doing so without obtaining the names of the people who will control or benefit from those companies... Most of our States allow hidden owners to buy companies online within 24 hours of a request. In two States, for an extra $\$ 1,000$, hidden owners can form a U.S. company within a single hour.

Levin goes on to expressly note that the United States is in violation of international standards on financial transparency, that it derives economic advantage from under-cutting the standards in this manner, and that this verdict confirms the results of the Tax Justice Network study referred to above. On each of these counts it also confirms the conclusions of this article. An earlier Government Accountability Office survey of American practice conveys the same message with its title alone: Company Formations: Minimal Ownership Information is Collected and Available (2006). Yet the problem remains unaddressed. Giving an indication of the consequences, in 2009 the World Bank compiled a database of the corporate vehicles used to launder the proceeds of major corruption. By November 2009 the database included 104 cases of grand corruption in which more than $\$ 1$ million was transferred internationally involving 295 identifiable corporate vehicles. The single most common jurisdiction of incorporation for the shell companies involved was the United States (43 instances) (see World Bank, "Misuse of Corporate Vehicles in Grand Corruption Cases, Progress Report 5,” 13 November 2009).

Although the United States is the worst offender, it is not the only one. A study for the European Commission, Euroshore: Protecting the EU Financial System from the Exploitation of 
Financial Centers and Offshore Facilities by Organized Crime (which did not survey the United States), also constructs an index of corporate secrecy. Despite the European Commission’s premise that the problem was offshore, the report finds that "the European Union member states have not 'cleaned up their acts' before asking others to do so" (Euroshore 2000: 15). Because the company law relating to beneficial ownership is "the most essential factor in the transparency of a financial system," the report concludes that EU members must first address their own serious failings in this area. Likewise, World-Check, the world's leading private firm for the provision of "Know Your Customer” (KYC) software, notes the divergence between conventional stereotypes and reality regarding the degree of due diligence exercised on- and offshore:

There is a false sense of security when carrying out due diligence on or dealing with an onshore company, trust, foundation or charity, in comparison to the equivalent offshore vehicles. The registration of a company in most onshore jurisdictions carries little or no KYC requirements on the beneficiaries, owners or company directors. The knowledge that a company is registered in the United Kingdom, the United States or in the EU, as opposed to some small tax haven island nation, for some reason would appear to make us think it must be above board (World-Check, “Refining the PEP Definition,” (2 ${ }^{\text {nd }}$ edition) 2008: 9). Coming full circle to the notion of a direct test is the exercise performed by two former US IRS officials in 2006, who used a Nevada corporate service provider to set up shell companies in New York, Florida and Panama, each with bank accounts, before wiring money from each company to the other. One of the officials observed "Surprisingly, it was more difficult to form an account there [in Panama] than it was in the U.S.” Panama required notarized copies 
of the passport page and driver's license, while the American institutions required neither. He concluded: “The U.S. beats up on these small island countries, from Antigua to Nauru to everyplace else, for not having adequate (corporate) controls, yet we have control problems in our states” ('Project Shows Ease of Money Laundering in the United States,” USA Today, 19 March 2007).

The evidence presented above from a wide range of sources broadly confirms the main conclusion of the direct tests employed: that in practice the rules prohibiting corporate anonymity have major effectiveness problems, and that powerful countries, especially the United States, are more at fault than small state offshore financial centres. The final task, then, is to briefly demonstrate why small states have been so stringent in enforcing rules that others routinely ignore. In keeping with the realist orientation of the article, the answer is that they are forced to. The example of the Bahamas is instructive in demonstrating hypocrite standards in action. This small, weak country was forced to implement expensive, purportedly international standards on corporate transparency by a coalition of powerful countries led by the United States, despite the fact that this latter group did not (and currently do not) meet the standards in question.

In June 2000 the Bahamas was blacklisted for failing to meet international standards on financial transparency, with removal from the list conditional upon adopting far-reaching regulatory reforms (Sharman 2009). A central demand was that all Bahamian shell companies be able to be traced to their real owners (FATF 2000: 3). All G7 members warned their financial institutions to exercise particular caution when transacting with the Bahamas. At their July 2000 summit the G7 heads of state announced "We are prepared to act together... to implement coordinated countermeasures against those [blacklisted jurisdictions] that do not take steps to 
reform their system appropriately, including the possibility to condition and restrict financial transactions with these jurisdictions"

(http://www.mofa.go.jp/policy/economy/summit/2000/pdfs/action.pdf). The Bahamian negotiating team was incensed to learn in discussions with its counterpart (led by a US official), that to be removed from the list all Bahamian corporate service providers had to be licensed, even though there was (and is) no such requirement in the United States or most other OECD states (Author’s interview; FATF 2006). The concessions extracted were far-reaching: "In a move that has their financial sector reeling, the Bahamas’ Premier told bankers, in August [2000], that the Bahamas will fully co-operate in international investigations, scrap secrecy laws and share tax information with the USA" (Johnson 2001: 213). The president of the Bahamas Bar Association was moved to denounce the decision as "capitulation to OECD terrorism" (http://www.freedomandprosperity.org/Papers/maynard/maynard.shtml). The Bahamas experienced considerable economic loss as a result of the concessions (Vlcek 2008: 122-5). In confidential interviews with officials from the Bahamian team, the FATF and the US Treasury, all three sources confirm that the Bahamas had simply given in to a coercive process in adopting the regulations (Author's interviews; see also Drezner 2007: 142-45). To add insult to injury, all sides knew that the Bahamas was being held to standards that the United States, Britain and other powerful states did not meet. Extensive interviews in other small states confirm the Bahamas’ experience as typical (Author's interviews in the Cayman Islands, the Cook Islands, Liechtenstein, Nauru, Panama, the Seychelles, St Kitts and Nevis, Vanuatu).

\section{Conclusion}


The article closes by re-emphasizing points on the significance of the substantive findings, and the method employed to generate them. The results of the direct test show a pattern of partial effectiveness (low for the formation of anonymous companies, much higher for anonymous banking), but even so the more variation in national compliance (low by G7 countries, much higher amongst those small states cast as tax havens). In relation to anonymous shell companies, the United States, United Kingdom and other OECD states, unlike the Cayman Islands and Panama, have simply chosen not to comply with international standards they had a large hand in creating. Nor is uneven progress in making these rules effective a result of a race to the bottom driven by regulatory arbitrage, or a prisoner's dilemma, whereby all states share the same preference, but rational anticipation of others' defection causes actors to refrain from cooperation. The "do as I say, not as I do" position of the G7 states towards smaller states is a good fit with a realist position concerning the power- rather than rule-governed nature of the international system. But unlike recent realist accounts of international standard-setting and effectiveness, it is not a case of core states or a hegemon adopting rules and then inducing others to follow their example (Krasner 1991; Gruber 2000; Drezner 2007). Instead, the hegemon and core states induce other states to follow rules that the former are not following themselves, perhaps analogous to the nuclear non-proliferation regime. Realist authors may thus have actually understated the influence of power in the selective application and impact of international rules.

Concerning the field more generally, the conventional story of progress in political science emphasizes the move away from studying formal rules towards behavior, as well as the employment of increasingly scientific methods. Given this orientation and scale of values, direct 
approaches like field experiments and participation are curiously scarce. Such methods can potentially shed light on a class of questions of great interest to scholars, policy-makers and citizens: do rules work, i.e., are they effective? Their lack of employment in political science to compliment existing techniques seems to indicate much more a failure of imagination in the field than any inherent shortcomings. No doubt there are many areas of interest where participant and field experiment approaches are impractical, unethical and/or illegal. Yet speaking only of International Relations, the extent to which issues like legalization, global governance and international regimes have become major controversies in the field argues for the potential of similar approaches. Soft law standards are amenable to testing by breaking. Civil society groups, epistemic communities, private firms, international organization and states are relatively porous to scholars looking to learn by participating in their activities. The opportunities to advance scholarly and policy knowledge through direct approaches are there; more political scientists should seize them. 


\section{BIBLIOGRAPHY}

Baldwin, David A. (Ed.) (1993) Neorealism and Neoliberalism: The Contemporary Debate. New York: Columbia University Press.

Barnett, Michael and Martha Finnemore. (2004) Rules for the World: International Organizations in Global Politics. Ithaca: Cornell University Press.

Bertrand, Marianne and Sendhil Mullainathan. (2004) Are Emily and Greg more Employable than Lakisha and Jamal? A Field Experiment on Labor Market Discrimination. American Economic Review 94 (4): 991-1013.

Carr, E.H. (1939) The Twenty Years’ Crisis 1919-1939. London: Macmillan.

de Soto, Hernando. (2002) [1989] The Other Path: The Economic Answer to Terrorism. New York: Basic Books.

de Soto, Hernando. (2000) The Mystery of Capital: Why Capitalism Triumphs in the West and Fails Everywhere Else. New York: Basic Books.

Drezner, Daniel. (2007) All Politics is Global: Explaining International Regulatory Regimes, Princeton: Princeton University Press. 
European Commission. (2008) Report from the Commission to the Council in Accordance with Article 18 of Directive 2003/48/EC on the Taxation of Savings Income in the Form of Interest Payments. Brussels.

Euroshore: (2000) Protecting the EU Financial System from the Exploitation of Financial Centers and Offshore Facilities by Organized Crime. Prepared for the European Commission. Treneto.

FATF. (2000) First Review to Identify Non-Co-operative Countries and Territories. Paris.

FATF. (2006) The Misuse of Corporate Vehicles, Including Trust and Corporate Service Providers. Paris.

FATF. (2009) Securing Timely Access to Beneficial Ownership Information (Legal Persons). Working Group on Evaluation and Implementation. 9 December. Washington DC.

Fisher, Howard. (2008) The Death of Offshore Secrecy-And it's not Resting in Peace. Offshore Investment. Issue 187: 11-19.

FSF. (2000) Report of the Working Group on Offshore Financial Centers. Basel. 
FSF. (2007) Financial Stability Forum Review of its Offshore Financial Centers Initiative. Press release 26 September.

G20. (2008) Declaration of the Summit on Financial Markets and the World Economy. 15 November. Available at http://www.whitehouse.gov/news/releases/2008/11/20081115-1.html.

G20. (2009) Communiqué: Meeting of Finance Ministers and Central Bank Governors. 7 November. Available at http://www.g20.org/Documents/2009_communique_standrews.pdf.

Gosnell, Harold. (1927) Getting Out the Vote: An Experiment in the Stimulation of Voting. Chicago: University of Chicago Press.

Goulder, Robert. (2009) How the U.S. Is a Tax Haven for Mexico’s Wealthy. http://www.taxanalysts.com/www/features.nsf/Articles/522A39903AFD6CFB8525761D004F11 3B?OpenDocument [Accessed 26 November 2009].

Green, Donald P. and Alan S. Gerber. (2002) Reclaiming the Experimental Tradition in Political Science. In Political Science: State of the Discipline, edited by Ira Katznelson and Helen V. Milner, pp.805-832, New York: W.W. Norton.

Gruber, Lloyd. (2000) Ruling the World: Power Politics and the rise of Supranational Institutions. Princeton: Princeton University Press. 
Haas, Peter M., Robert O. Keohane and Marc A. Levy (Eds). (1993) Institutions for the Earth: Sources of Effective International Environmental Protection. Cambridge Mass.: MIT Press.

Johnson, Jackie. (2001) Blacklisting: Initial Reactions, Responses and Repercussions. Journal of Money Laundering Control. 4 (3): 211-25.

Keohane, Robert O. (1984) After Hegemony: Co-operation and Discord in the World Political Economy. Princeton: Princeton University Press.

Keohane, Robert O. (2009) The Old IPE and the New. Review of International Political Economy 16 (1): 34-46.

King, Gary, Robert O. Keohane and Sidney Verba. (1994) Designing Social Inquiry: Scientific Inference in Qualitative Research. Princeton: Princeton University Press.

Kirshner, Jonathan. (2009) Realist Political Economy: Traditional Themes and Contemporary Challenges. In Routledge Handbook of International Political Economy: IPE as a Global Conversation, edited by Mark Blyth. London: Routledge, pp.36-48

Krasner, Stephen D. (1977) US Commercial and Monetary Policy: Unravelling the Paradox of External Strength and Internal Weakness. International Organization 31 (4): 635-671. 
Krasner, Stephen D. (1991) Global Communications and National Power: Life on the Pareto Frontier. World Politics 43 (3): 336-366.

Lake, David A. (2007) Escape from the State of Nature: Authority and Hierarchy in World Politics. International Security 32 (1): 47-79.

Langer, Marshall J. (2008) Offshore for more than 50 Years. Offshore Investment. Issue 182: 910.

Maliniak, Dan and Michael J. Tierney. (2009) The American School of IPE. Review of International Political Economy 16 (1): 6-33.

Mearsheimer, John J. (1994/95) The False Promise of International Institutions. International Security 19 (3): 5-49.

Mearsheimer. John J. (2001) The Tragedy of Great Power Politics. New York. W.W. Norton.

Nye, Joseph S. Foreword. (1993) In Institutions for the Earth: Sources of Effective International Environmental Protection, edited by Peter M. Haas, Robert O. Keohane and Marc A. Levy Cambridge Mass.: MIT Press. 
OECD. (2001) Behind the Corporate Veil: Using Corporate Entities for Illicit Purposes. Paris. Popper, Karl. (1968) The Logic of Scientific Discovery. New York: Harper and Row.

Raustiala, Kal and Anne-Marie Slaughter. (2002) International Law, International Relations and Compliance. In Handbook of International Relations edited by Walter Carlsnaes, Thomas Risse and Beth A. Simmons, pp.538-558, Thousand Oaks Calif.: Sage.

Senate Permanent Subcommittee on Investigations. (2008) Tax Haven Banks and US Tax Compliance. United States Senate. Washington DC.

Sharman, J.C. (2008) Regional Deals and the Global Imperative: The External Dimension of the European Union Savings Tax Directive. Journal of Common Market Studies 46 (4): 1049-1069.

Sharman, J.C. (2009) The Bark is the Bite: International Organizations and Blacklisting. Review of International Political Economy 16 (5): 573-596.

Sheppard, Lee A. (2009) Dear Former Tax Evasion Services Customer. Tax Notes International 56 (2): 91-95

Simmons, Beth A. (1998) Compliance with International Agreements. Annual Review of Political Science. 1: 75-93. 
Simmons, Beth A. (2000) International Law and State Behavior: Commitment and Compliance in International Monetary Affairs. American Political Science Review 94 (4): 819-835.

United Nations Office for Drug Control and Crime Prevention. (1998) Financial Havens, Banking Secrecy and Money Laundering. Prepared by Jack A. Blum, Michael Levi, R. Thomas Naylor, and Phil Williams. Washington D.C.

UNODC-World Bank. (2007) Stolen Assets Recovery (StAR) Initiative: Challenges, Opportunities and Action Plan. Washington DC.

Vlcek, William. (2008) Offshore Finance and Small States: Sovereignty, Size and Money. New York: Palgrave.

World Bank. (2009) Laundering the Proceeds of Public Sector Corruption. Prepared by Richard Gordon. Washington DC.

Young, Oran. (1979) Compliance with Public Authority. Baltimore: Johns Hopkins University Press. 
TABLE 1: Prohibitions on Anonymous Companies \& Accounts

\begin{tabular}{|l|l|l|}
\hline Body & Instrument & Clause \\
\hline United Nations & $\begin{array}{l}\text { Convention Against } \\
\text { Corruption }\end{array}$ & Article 52 \\
\hline OECD & $\begin{array}{l}\text { Principles of } \\
\text { Corporate } \\
\text { Governance }\end{array}$ & Chapter V A 3 \\
\hline FATF & $\begin{array}{l}40+9 \\
\text { Recommendations }\end{array}$ & $\begin{array}{l}\text { Recommendations 5, } \\
\text { Basel Committee }\end{array}$ \\
$\begin{array}{l}\text { Basel Core Principles } \\
\text { Basel Core Principle } \\
18\end{array}$ \\
\hline IOSCO & $\begin{array}{l}\text { Multilateral } \\
\text { Memorandum of } \\
\text { Understanding }\end{array}$ & Paragraph 7 b (ii) \\
\hline
\end{tabular}


TABLE 2: Results

\begin{tabular}{|c|c|c|c|c|}
\hline Service Provider & Shell Company & ID Required? & Bank & ID Required? \\
\hline Bahamas & Anguilla & Yes & & \\
\hline Bahamas & Bahamas & Yes & & \\
\hline Bahamas & Bahamas & Yes & & \\
\hline Belize & Belize & Yes & & \\
\hline Bermuda & Bermuda & Yes & & \\
\hline $\begin{array}{l}\text { British Virgin } \\
\text { Islands (BVI) }\end{array}$ & BVI & Yes & & \\
\hline Cayman Islands & Cayman Islands & Yes & & \\
\hline Cayman Islands & Cayman Islands & Yes & & \\
\hline Cyprus & $\begin{array}{l}\text { BVI, Panama, St } \\
\text { Vincent }\end{array}$ & Yes & & \\
\hline Czech Republic & BVI, Seychelles & Yes & & \\
\hline Dominica & Dominica & Yes & & \\
\hline Gibraltar & Turks \& Caicos & Yes & & \\
\hline Gibraltar & $\begin{array}{l}\text { BVI, Delaware, } \\
\text { Gibraltar, Panama, } \\
\text { Wyoming, etc. }\end{array}$ & Yes & & \\
\hline Hong Kong & BVI & Yes & & \\
\hline Hong Kong & $\begin{array}{l}\text { BVI, Hong Kong, } \\
\text { Seychelles, etc. }\end{array}$ & Yes & & \\
\hline Hong Kong & BVI & Yes & & \\
\hline Labuan (Malaysia) & Labuan & Yes & & \\
\hline Liechtenstein & Liechtenstein & Yes & & \\
\hline Nauru & Nauru & Yes & & \\
\hline Panama & Panama & Yes & & \\
\hline Panama & Panama & Yes & & \\
\hline Panama & $\begin{array}{l}\text { Belize, Nevis, } \\
\text { Panama, Seychelles, } \\
\text { Vanuatu, etc. }\end{array}$ & Yes & & \\
\hline Sao Tome & Sao Tome & Yes & & \\
\hline
\end{tabular}




\begin{tabular}{|c|c|c|c|c|}
\hline Seychelles & BVI, Seychelles & Yes & & \\
\hline Singapore & $\begin{array}{l}\text { Bahamas, BVI, } \\
\text { Delaware }\end{array}$ & Yes & & \\
\hline Singapore & Singapore & Yes & & \\
\hline Switzerland & $\begin{array}{l}\text { BVI, Delaware, } \\
\text { Panama }\end{array}$ & Yes & & \\
\hline Belize & Belize & No & Belize & Yes \\
\hline Canada & $\begin{array}{l}\text { BVI, Ontario, } \\
\text { Panama, Wyoming, } \\
\text { etc. }\end{array}$ & No & Latvia, Panama & Yes \\
\hline Hong Kong & Delaware & No & Hong Kong & Yes \\
\hline Singapore & $\begin{array}{l}\text { BVI, Hong Kong, } \\
\text { Seychelles (Gruppo } \\
\text { 20) }\end{array}$ & No & Cyprus & Yes \\
\hline Spain & Belize & No & Belize & Yes \\
\hline UK & $\begin{array}{l}\text { Belize, BVI } \\
\text { England, Nevada, } \\
\text { Panama, etc. }\end{array}$ & No & Isle of Man & Yes \\
\hline UK & Belize & No & Hong Kong & Yes \\
\hline UK & Cyprus & No & Cyprus & Yes \\
\hline UK & $\begin{array}{l}\text { Belize, BVI, } \\
\text { Delaware, England, } \\
\text { etc. }\end{array}$ & No & Hong Kong & Yes \\
\hline UK & England (A. Pascal) & No & Latvia & No (pre-2007), Yes \\
\hline Uruguay & Seychelles & No & $\begin{array}{l}\text { Hong Kong, } \\
\text { Panama }\end{array}$ & Yes \\
\hline US & Wyoming & No & US & Yes \\
\hline US & Nevis & No & Belize & Yes \\
\hline Liechtenstein & Somalia & Yes & Somalia & Yes (unnotarized) \\
\hline UK & $\begin{array}{l}\text { Belize, BVI, } \\
\text { Delaware, Nevada, } \\
\text { Panama, etc. }\end{array}$ & No & St Vincent & Yes (unnotarized) \\
\hline UK & Seychelles & No & Montenegro & Yes (unnotarized) \\
\hline US & $\begin{array}{l}\text { Nevada (BCP } \\
\text { Consolidated) }\end{array}$ & No & US & Yes (unnotarized) \\
\hline
\end{tabular}




\begin{tabular}{|l|l|l|l|l|}
\hline US & Wyoming & No & US & $\begin{array}{l}\text { No (pre-2008), Yes } \\
\text { (unnotarized) }\end{array}$ \\
\hline
\end{tabular}

